\title{
To Study the Pre and Post-Harvest Constraints and Prospects Level Confronted by the Marigold (Tagetes erecta L.) Growers in Gurugram and Jhajjar Districts of Haryana, India
}

\author{
Pankaj Yadav* and D. S. Dahiya \\ Department of Horticulture, Maharana Pratap Horticultural University, \\ Karnal, Haryana, India \\ *Corresponding author
}

Keywords

Marigold,

Prospects, Pre and

post harvest,

Technical guidance,

Constraints

Article Info

Accepted:

14 May 2020

Available Online:

10 June 2020
A B S T R A C T

\begin{abstract}
The present study was conducted in Gurugram and Jhajjar districts of Haryana state. From both districts, two blocks were selected randomly i.e. Farrukh agar and Gurgaon from the district Gurugram and Jhajjar and Bahadurgarh from the district Jhajjar. From each selected block, 20 growers selected randomly, thus making a total 80 farmers who were involved in marigold cultivation. The study revealed that, majority of the respondents were middle aged, had graduation level of education, with service and agriculture as their main occupation, having small family size, living as joint families, and having large landholding size. Majority of the respondents were found listening to radio krishi programmes as their mass media exposure. In case extension contacts majority of the respondents were found in contact with the ADO/VEW. Regarding concept, importance, harvesting, packing and marketing of marigold majority of the respondents had medium level of knowledge. In the case of agronomic practices and fertilizers application majority of the respondents belonged to a low level of knowledge.
\end{abstract}

\section{Introduction}

The floriculture business is very fast emerging as a major venture on the world scenario. Flower cultivation is an ancient farm activity with great potential for generating remunerative self-employment among the small and marginal farmers besides earning the much needed foreign exchange. Marigold is one of the most important flower crops growing for the flower production as loose flowers are used in different areas like cosmetic preparation, medicines as well as it is most widely used as ornamentals. It is found in different colours and different fragrances among them yellow color is most common.

In India marigold is one of the most commonly grown flowers and used extensively on religious and social functions in different forms. 
Because of their ease in cultivation, wide adaptability to varying soil and climatic conditions, long duration of flowering and attractively colored flowers of excellent keeping quality, the marigolds have become one of the most popular flowers in our country. Flowers are sold in the market as loose or as garlands.

Marigold (Tagetes erecta) spps. belong to family Asteraceae. Generally grown on well drained loamy soil. The environmental conditions after the seedlings are transplanted markedly influence the growth and flowering. Mild climate during the growing period (14.5 $-28.6{ }^{\circ} \mathrm{C}$ ) greatly improves flowering while higher temperatures $\left(26.2-36.4^{\circ} \mathrm{C}\right)$ adversely affect flower production. The soil $\mathrm{pH}$ should be 7.0 to 7.5. Saline and acidic soils are not suitable for cultivation.

The seeds are sown throughout the year. Nursery is raised with $400 \mathrm{~g}$ seeds/ha and the seedlings are transplanted after four weeks on one side of the ridge at $45 \times 35 \mathrm{~cm}$ spacing. During last ploughing, incorporate 25t/ha of FYM. Apply 45:90:75 kg NPK/ha as basal and $45 \mathrm{~kg} \mathrm{~N} / \mathrm{ha}$ as top dressing 45 days after planting. After cultivation weeding should be done as and when necessary. Irrigation should be given immediately after planting and life irrigation on the third day after planting. Water stagnation should be avoided.

15 varieties were evaluated of which Co-1 marigold $(30 \mathrm{~kg} / \mathrm{sqm})$ performed best followed Pusa Narangi (gaindha). Due to higher flower production Pusa Narangi is mostly preferred by Namdhari marigold, First Lady and Pusa Narangi. Pinching of terminal leaves was found to significantly increase growth and yield in Pusa Basanti.

In India, area under Marigold in 2015 was 65,000 ha and production was $6,16,000$ tonnes (Ministry of Agriculture and Farmers'
Welfare, GOI, 2016-17). The area under marigold cultivation in Haryana during 201415 was 5,380 ha producing about 62,340 tonnes with an average yield of $11.58 \mathrm{t} / \mathrm{ha}$ (Ministry of Agriculture and Farmers' Welfare, GOI, 2014-15). The area under marigold cultivation in Haryana was about 344 ha producing about 1,560 tonnes with an average yield of $4.54 \mathrm{t} / \mathrm{ha}$. The annual growth rate of area, production, and yield of marigold for the period from 2007-2008 to 2009-2010 were $12.44 \%, 11.12 \%$, and $-1.32 \%$, respectively. In Haryana, 61.83 thousands tonnes of loose flowers were produced in 2015-16. Regarding cultivation of flower crop, marigold dominated in north Haryana $79.17 \%$.

In Haryana, the area under flower cultivation covers 8200 hectares of which the maximum area is under marigold i.e. 6481 hectares. In Gurugram production and area in 2016 of marigold was 1020 tonnes from an area of 92 ha which reduced to 940 tonnes in 2017 from an area of 82 ha (Horticulture Department, Gurugram). In Jhajjar, area under Marigold was 53 ha, and production was 520 tonnes (hortharyana.gov.in, Annual Report 2015-16).

\section{Materials and Methods}

The study was conducted in Haryana state, in two districts Gurugram and Jhajjar selected purposely, further, four blocks were selected, randomly from each district. From the selected blocks twenty marigold cultivators were selected randomly for the study. A total of eighty respondents were finalized from the two selected districts for the study.

Variables were selected in accordance with the objectives of study while selecting the variables adequate attention was paid to review of literature collected for the purpose of the study. The constraints were categorized into five broad heads namely inputs, 
marketing, production, technical guidance and psychological constraints perceived by the respondents. The respondents were asked to response on three point continuum i.e. 'Very Serious', 'Serious' and 'Not Serious' about the nature of the constraints.

The weights were also assigned in the order 3 , 2 and 1 respectively. So, that it can be concluded that higher the score the more severe the constraints as perceived by the members of the marigold growers.

\section{Results and Discussion}

Keeping in view the constraints faced by the respondents, an attempt was made to know the forces that impede the respondents. All the constraints were grouped into five categories related to input constraints, market constraints, production constraints, technical guidance constraints and psychological constraints.

Constraints perceived by the respondents in adoption of recommended cultivation practices of marigold

The data in Table 1 revealed that the constraints related to Input, majority of the respondents 85.00 per cent considered "Nonavailability of certified seeds" very serious problem followed by "Lack of finance for the purchase of inputs" 60.00 per cent, "High price of insecticides/pesticides and fungicides" 90.00 per cent, "Non-availability of inputs at proper time" 72.50 per cent and "Non-availability of labour / high labour charges"100.00 per cent respectively.

The data indicates that in case of constraints related to market the majority of the respondents 72.50 per cent considered very serious problem "Lack of domestic commodity market" followed by, "Lack of guidance for proper time and place of marketing" 60.00 per cent, "Lack of proper storage facility" 77.50 per cent, "Lack of transport facilities and disposal of produce" 86.25 per cent" and "High post-harvest losses during transportation" 82.50 per cent.

The data indicates that in case of constraints related to production the majority of the respondents 56.25 per cent considered most serious constraint "Unfavourable agroclimatic conditions", followed by "Farmer and labour are not skilled due to lack of trainings" 100.00 per cent, "Lack of proper cropping sequence followed by farmers" 100.00 per cent and "Non-awareness about proper and balanced fertilizer application and time of application" 80.00 per cent respectively. These findings closely resemble the findings of Ramamurthi et.al. (1997) reported that the adoption level of farmers had medium $(56.7 \%)$ followed by low $(30.8 \%)$ and high $(12.5 \%)$ on turmeric production and processing.

In case of constraints related to technical guidance the majority of the respondents 72.50 per cent considered "Lack of knowledge of current advances for marigold cultivation" serious constraint followed by "Lack of guidance for selecting varieties and fertilizer application" 78.75 per cent, "Lack of guidance for controlling insect-pests and application of pesticides and fungicides" 61.25 per cent and "Extension gap" as not serious problem with 61.25 per cent respectively. These findings closely resemble the findings of Chand (1994) he revealed in his findings lack of knowledge as a major constraint in his study.

In case of technological constraints related to respondents the majority of the respondents 61.25 per cent considered major problem "Notion of more irrigation requirements" followed by "Self marketing is a problem" 42.50 per cent as not so serious problem. 
Constraints perceived by the respondents during pre and post-harvest practices of marigold cultivation categorized into various categories to draw valuable inferences

The results in the Table 2 indicates a comparative picture regarding low, medium and high responses against different constraints which respondents come across while practicing marigold cultivation starting from harvesting to the adoption of postharvest management practices.

It is apparent from Table ' $\mathrm{A}$ ' part that among the constraints related to inputs the majority of the respondents 60.00 per cent belong to the low category followed by 35.00 per cent in the medium category and only 05.00 per cent in the high category.

The constraints were perceived by flower growers were, such as non-availability of inputs at proper time, non- availability of quality seeds, high price of insecticides/pesticides and fungicides, nonavailability of labour or high charges of labour and lack of finance purchase of inputs, were found major constraints because of no specific information about input quality and price of pesticides. Similar results observed by Kamboj Moji (2011) low production is due to non-availability of inputs and due to unfavourable weather conditions, absence of agro processing units and lack of knowledge were major constraints.

It is recorded from Table ' $\mathrm{B}$ ' part that the constraints related to market the majority of the respondents 52.50 per cent were belong to low category followed by 32.50 per cent in medium category and only 15.00 per cent in high category. The constraints related to marketing perceived major constraints were no support prices of flowers, followed by absence of processing units, problems of storage, lack of guidance for proper time and place of marketing, lack of transport facilities and high transportation costs.

The present study was found in line with the study of Devi Nirmala and Manmohan (1998) various constraints analyzed it was observed that the market constraints low price for the produce $(74.25 \%)$, followed by lack of quick transportation facilities (58.59\%), lack of storage facilities (51.09\%), non-availability by middle man (34.36\%) till lifted for marketing and non-availability of processing units in the nearby areas (32.26\%) constraints.

The data contained in Table ' $\mathrm{C}$ ' part indicated that constraints related to production, the majority of the respondents 56.25 per cent were belong to medium category followed by 32.50 per cent in low category and only 11.25 per cent in high category.

Constraints related to production of marigold cultivation such as, unfavourable agroclimatic conditions was major constraint, followed by non-awareness about proper application of fertilizers, lack of proper cropping sequence followed by farmers and unskilled labours due to lack of trainings. Some of the results were found similar to Manju et al., (2010) that the majority of the farmers had given the high score to lack of awareness about varieties, application of fertilizers, time of application of fertilizers and lack of training. It is evident from the Table ' $\mathrm{D}$ ' part that constraints related to technical guidance, the majority of the respondents 47.50 per cent belong to the medium category followed by 30 per cent in high category and 22.50 per cent in low category. Constraints related to technical guidance including lack of knowledge of post application, lack of guidance for controlling insect pest and diseases, lack of guidance for treatment, extension gap, lack of guidance of post-harvest technology, lack of knowledge 
about current advances for flower cultivation and lack of knowledge about fertilizer application. The findings were found similar to constraints reported by Shrivastava et al., (2010) observed that the lack of knowledge about appropriate chemicals and fungicides, non-availability of plant protection equipment, lack of technical guidance, high cost of fungicides and sale of spurious agrochemicals.

The data contained in Table ' $E$ ' part indicated that psychological constraints as perceived by respondents, the majority of the respondents 48.75 per cent were belong to low category followed by 36.25 per cent in medium category and only 15.00 per cent in high category. Psychological constraints perceived by the respondents include self-marketing as a major constraint followed by notion of more irrigation requirements. The similar results was reported by Sanjeev and Singha (2010), that as psychological constraint major constraint perceived by the respondent was marketing followed by low produce, low prices or no remunerative prices, intensive labour requirements and non-availability of good irrigation facilities.

\section{Prospects level of the marigold growers in the study area}

Table 3 elaborates the areas from which flower growers "perceived brighter prospect with respect to the marigold cultivation. The weighted differences of prospects and rank order of different items revealed that the respondents perceived as Better for only those who are residing near the city, was 1 st ranked (weighted mean 2.86). Better market facilities are available at present as perceived $2 \mathrm{nd}$ rank (weighted mean 2.50), better technical support is available, better flower quality, and Increased diversification were ranked 3rd (weighted mean 2.45), 4th (weighted mean 2.36), and 5th (weighted mean 2.21), respectively similar prospect was also reported by Katyayan (1989) that the demand of flowers and its cultivated area is increasing fast. Better credit facilities are available at present was ranked 6th (weighted mean 2.11), Better input facilities are available was ranked 7th (weighted mean 2.00), Better economic returns, High demand of flowers and Purchasing power of people is increasing were ranked 8th (weighted mean 1.98), 9th (weighted mean 1.91), and 10th (weighted mean 1.85) respectively. Less dependency upon cereal crops was ranked 11th (weighted mean 1.73), and high price of produce ranked 12th (weighted mean 1.72) is the least prospect preferred by the respondents.

In case of prospects of marigold cultivation indicated that cultivation of marigold is good for those who are residing near cities; perceived major prospect by the farmers followed by better market facilities are available as marketing occupies an important place as it provides linkages between the producers and the ultimate consumers, better flower quality, better technical support, means better use of technologies for the cultivation of marigold crops. The findings were found in line with the findings of Balasubramaniam (1996) studied the techno economic aspect of raising carnation cut flowers.

While increased diversification, better input facilities are available, better economic returns, high price of produce, high demand of flowers, purchasing power of people is increasing, less dependency upon cereal crops and demand is increasing is the least prospect preferred by the respondents. The findings were found in line with the findings of Mukherjee, D. (1997) studied prospects and problems of commercial floriculture, he found that majority of the respondents ${ }^{\text {ee }}$ perceived marketing as major prospects followed by quality, technical support and increase in farmers ${ }^{\text {ee }}$ purchasing power. 
Table.1 Constraints perceived by the respondents in adoption of recommended cultivation practices of Marigold $(n=80)$

\begin{tabular}{|c|c|c|c|c|}
\hline \multirow{2}{*}{$\begin{array}{l}\text { Sr. } \\
\text { No }\end{array}$} & \multirow[t]{2}{*}{ Statements } & \multicolumn{3}{|c|}{ Degree of seriousness } \\
\hline & & $\begin{array}{c}\text { Very } \\
\text { serious (3) }\end{array}$ & $\begin{array}{l}\text { Serious } \\
\text { (2) }\end{array}$ & $\begin{array}{c}\text { Not so serious } \\
\text { (1) }\end{array}$ \\
\hline \multicolumn{5}{|c|}{ A. Constraints related to Input } \\
\hline 1 & Non-availability of certified seeds & $\begin{array}{c}68 \\
(85.00)\end{array}$ & $\begin{array}{c}12 \\
(15.00)\end{array}$ & $\begin{array}{c}00 \\
(00.00)\end{array}$ \\
\hline 2 & Lack of finance for the purchase of inputs & $\begin{array}{c}48 \\
(60.00)\end{array}$ & $\begin{array}{c}28 \\
(35.00)\end{array}$ & $\begin{array}{c}04 \\
(05.00)\end{array}$ \\
\hline 3 & $\begin{array}{l}\text { High price of insecticides /pesticides and } \\
\text { fungicides }\end{array}$ & $\begin{array}{c}72 \\
(90.00)\end{array}$ & $\begin{array}{c}08 \\
(10.00)\end{array}$ & $\begin{array}{c}00 \\
(00.00)\end{array}$ \\
\hline 4 & Non-availability of inputs at proper time & $\begin{array}{c}58 \\
(72.50)\end{array}$ & $\begin{array}{c}22 \\
(27.50)\end{array}$ & $\begin{array}{c}00 \\
(00.00)\end{array}$ \\
\hline 5 & $\begin{array}{l}\text { Non-availability of labour / high labour } \\
\text { charges }\end{array}$ & $\begin{array}{c}80 \\
(100.00)\end{array}$ & $\begin{array}{c}00 \\
(00.00)\end{array}$ & $\begin{array}{c}00 \\
(00.00)\end{array}$ \\
\hline \multicolumn{5}{|c|}{ B. Constraints related to market } \\
\hline 1 & Lack of domestic commodity market & $\begin{array}{c}58 \\
(72.50)\end{array}$ & $\begin{array}{c}12 \\
(15.00)\end{array}$ & $\begin{array}{c}10 \\
(12.50)\end{array}$ \\
\hline 2 & $\begin{array}{l}\text { Lack of guidance for proper time and } \\
\text { place of marketing }\end{array}$ & $\begin{array}{c}48 \\
(60.00)\end{array}$ & $\begin{array}{c}26 \\
(32.50)\end{array}$ & $\begin{array}{c}06 \\
(07.50)\end{array}$ \\
\hline 3 & Lack of proper storage facility & $\begin{array}{c}62 \\
(77.50)\end{array}$ & $\begin{array}{c}18 \\
(22.50)\end{array}$ & $\begin{array}{c}00 \\
(00.00)\end{array}$ \\
\hline 4 & No support price of produce & $\begin{array}{c}80 \\
(100.00)\end{array}$ & $\begin{array}{c}00 \\
(00.00)\end{array}$ & $\begin{array}{c}00 \\
(00.00)\end{array}$ \\
\hline 5 & $\begin{array}{l}\text { Lack of transport facilities and disposal of } \\
\text { produce }\end{array}$ & $\begin{array}{c}69 \\
(86.25)\end{array}$ & $\begin{array}{c}11 \\
(13.75)\end{array}$ & $\begin{array}{c}00 \\
(00.00)\end{array}$ \\
\hline 6 & High transportation cost & $\begin{array}{c}48 \\
(60.00)\end{array}$ & $\begin{array}{c}18 \\
(22.50)\end{array}$ & $\begin{array}{c}14 \\
(17.50)\end{array}$ \\
\hline 7 & $\begin{array}{l}\text { High post harvest losses during } \\
\text { transportation }\end{array}$ & $\begin{array}{c}66 \\
(82.50)\end{array}$ & $\begin{array}{c}14 \\
(17.50)\end{array}$ & $\begin{array}{c}00 \\
(00.00)\end{array}$ \\
\hline \multicolumn{5}{|c|}{ C. Constraints related to production } \\
\hline 1 & Unfavourable agro-climatic conditions & $\begin{array}{c}45 \\
(56.25)\end{array}$ & $\begin{array}{c}26 \\
(32.50)\end{array}$ & $\begin{array}{c}09 \\
(11.25)\end{array}$ \\
\hline 2 & $\begin{array}{l}\text { Farmer and labour are not skilled due to } \\
\text { lack of trainings }\end{array}$ & $\begin{array}{c}80 \\
(100.00)\end{array}$ & $\begin{array}{c}00 \\
(00.00)\end{array}$ & $\begin{array}{c}00 \\
(00.00)\end{array}$ \\
\hline 3 & $\begin{array}{l}\text { Lack of proper cropping sequence } \\
\text { followed by farmers }\end{array}$ & $\begin{array}{c}80 \\
(100.00)\end{array}$ & $\begin{array}{c}00 \\
(00.00)\end{array}$ & $\begin{array}{c}00 \\
(00.00)\end{array}$ \\
\hline 4 & $\begin{array}{l}\text { Non-awareness about proper and balanced } \\
\text { fertilizer application and time of } \\
\text { application }\end{array}$ & $\begin{array}{c}64 \\
(80.00)\end{array}$ & $\begin{array}{c}16 \\
(20.00)\end{array}$ & $\begin{array}{c}00 \\
(00.00)\end{array}$ \\
\hline \multicolumn{5}{|c|}{ D. Constraints related to technical guidance } \\
\hline 1 & $\begin{array}{l}\text { Lack of knowledge of current advances } \\
\text { for marigold cultivation }\end{array}$ & $\begin{array}{c}58 \\
(72.50)\end{array}$ & $\begin{array}{c}28 \\
(35.00)\end{array}$ & $\begin{array}{c}04 \\
(05.00)\end{array}$ \\
\hline
\end{tabular}




\begin{tabular}{|c|c|c|c|c|}
\hline 2 & $\begin{array}{l}\text { Lack of guidance for selecting varieties } \\
\text { and fertilizer application }\end{array}$ & $\begin{array}{c}63 \\
(78.75)\end{array}$ & $\begin{array}{c}17 \\
(21.25)\end{array}$ & $\begin{array}{c}00 \\
(00.00)\end{array}$ \\
\hline 3 & $\begin{array}{l}\text { Lack of guidance for controlling insect- } \\
\text { pests and application of pesticides and } \\
\text { fungicides }\end{array}$ & $\begin{array}{c}49 \\
(61.25)\end{array}$ & $\begin{array}{c}31 \\
(38.75)\end{array}$ & $\begin{array}{c}00 \\
(00.00)\end{array}$ \\
\hline 4 & $\begin{array}{l}\text { Lack of guidance of post-harvest } \\
\text { technology }\end{array}$ & $\begin{array}{c}80 \\
(100.00)\end{array}$ & $\begin{array}{c}00 \\
(00.00)\end{array}$ & $\begin{array}{c}00 \\
(00.00)\end{array}$ \\
\hline 5 & Extension gap & $\begin{array}{c}28 \\
(35.00)\end{array}$ & $\begin{array}{c}03 \\
(03.75)\end{array}$ & $\begin{array}{c}49 \\
(61.25)\end{array}$ \\
\hline \multicolumn{5}{|c|}{ E. Technological constraints related respondents } \\
\hline 1 & Notion of more irrigation requirements & $\begin{array}{c}49 \\
(61.25)\end{array}$ & $\begin{array}{c}31 \\
(38.75)\end{array}$ & $\begin{array}{c}00 \\
(00.00)\end{array}$ \\
\hline 2 & Self marketing is a problem & $\begin{array}{c}18 \\
(22.50)\end{array}$ & $\begin{array}{c}28 \\
(35.00)\end{array}$ & $\begin{array}{c}34 \\
(42.50)\end{array}$ \\
\hline
\end{tabular}

** Parenthesis indicate the respective percentages

Table.2 Constraints perceived by the respondents during pre and post-harvest practices of Marigold cultivation categorised into various categories $(n=80)$

\begin{tabular}{|c|c|c|c|c|}
\hline Sr. No. & Constraints & Class range & Frequency & Percentage \\
\hline \multicolumn{5}{|c|}{ A. Constraints related to Input } \\
\hline 1 & Low & $5-7$ & 48 & 60.00 \\
\hline 2 & Medium & $8-10$ & 28 & 35.00 \\
\hline 3 & High & $>10$ & 04 & 05.00 \\
\hline \multicolumn{5}{|c|}{ B. Constraints related to market } \\
\hline 1 & Low & $9-13$ & 42 & 52.50 \\
\hline 2 & Medium & $14-18$ & 26 & 32.50 \\
\hline 3 & High & $>18$ & 12 & 15.00 \\
\hline \multicolumn{5}{|c|}{ C. Constraints related to production } \\
\hline 1 & Low & $4-5$ & 26 & 32.50 \\
\hline 2 & Medium & 6-7 & 45 & 56.25 \\
\hline 3 & High & $>7$ & 09 & 11.25 \\
\hline \multicolumn{5}{|c|}{ D. Constraints related to technical guidance } \\
\hline 1 & Low & $7-8$ & 18 & 22.50 \\
\hline 2 & Medium & $9-10$ & 38 & 47.50 \\
\hline 3 & High & $>10$ & 24 & 30.00 \\
\hline \multicolumn{5}{|c|}{ E. Technological constraints related respondents } \\
\hline 1 & Low & $2-3$ & 39 & 48.75 \\
\hline 2 & Medium & $4-5$ & 29 & 36.25 \\
\hline 3 & High & $>5$ & 12 & 15.00 \\
\hline
\end{tabular}


Table.3 Prospects level of the marigold growers in the study area $(n=80)$

\begin{tabular}{|c|c|c|c|c|c|c|c|}
\hline \multirow{2}{*}{$\begin{array}{l}\text { Sr. } \\
\text { No. }\end{array}$} & \multirow[t]{2}{*}{ Category } & \multicolumn{3}{|c|}{ Level of prospects } & \multirow{2}{*}{$\begin{array}{c}\text { Total } \\
\text { weighted } \\
\text { score }\end{array}$} & \multirow{2}{*}{$\begin{array}{l}\text { Weighted } \\
\text { mean } \\
\text { score }\end{array}$} & \multirow[t]{2}{*}{ Rank } \\
\hline & & $\begin{array}{l}\text { More } \\
\text { bright } \\
\text { (3) }\end{array}$ & $\begin{array}{c}\text { Somewhat } \\
\text { bright } \\
\text { (2) }\end{array}$ & $\begin{array}{l}\text { Bright } \\
\text { (1) }\end{array}$ & & & \\
\hline 1 & $\begin{array}{l}\text { High price for } \\
\text { produce }\end{array}$ & $\begin{array}{c}00 \\
(00.00)\end{array}$ & $\begin{array}{c}58 \\
(72.50)\end{array}$ & $\begin{array}{c}22 \\
(27.50)\end{array}$ & 138 & 1.72 & XII \\
\hline 2 & $\begin{array}{l}\text { Better flower } \\
\text { quality }\end{array}$ & $29(36.25)$ & $\begin{array}{c}51 \\
(63.75)\end{array}$ & $\begin{array}{c}00 \\
(0.00)\end{array}$ & 189 & 2.36 & IV \\
\hline 3 & $\begin{array}{l}\text { Better economic } \\
\text { returns }\end{array}$ & $\begin{array}{c}15 \\
(18.75)\end{array}$ & $\begin{array}{c}49 \\
(61.25)\end{array}$ & $\begin{array}{c}16 \\
(20.00)\end{array}$ & 159 & 1.98 & VIII \\
\hline 4 & $\begin{array}{l}\text { Demand is } \\
\text { increasing }\end{array}$ & $00(0.00)$ & $\begin{array}{c}40 \\
(50.00)\end{array}$ & $\begin{array}{c}40 \\
(50.00)\end{array}$ & 120 & 1.50 & XIII \\
\hline 5 & $\begin{array}{l}\text { Better technical } \\
\text { support is } \\
\text { available }\end{array}$ & $41(51.25)$ & $34(42.50)$ & $\begin{array}{c}05 \\
(06.25)\end{array}$ & 196 & 2.45 & III \\
\hline 6 & $\begin{array}{l}\text { Better credit } \\
\text { facilities are } \\
\text { available at } \\
\text { present }\end{array}$ & $\begin{array}{c}18 \\
(22.50)\end{array}$ & $\begin{array}{c}53 \\
(66.25)\end{array}$ & $\begin{array}{c}09 \\
(11.25)\end{array}$ & 169 & 2.11 & VI \\
\hline 7 & $\begin{array}{l}\text { High demand of } \\
\text { flowers }\end{array}$ & $\begin{array}{c}22 \\
(27.50)\end{array}$ & $\begin{array}{c}29 \\
(36.25)\end{array}$ & $\begin{array}{c}29 \\
(36.25)\end{array}$ & 153 & 1.91 & IX \\
\hline 8 & $\begin{array}{l}\text { Purchasing } \\
\text { power of people } \\
\text { is increasing }\end{array}$ & $\begin{array}{c}14 \\
(17.50)\end{array}$ & $\begin{array}{c}40 \\
(50.00)\end{array}$ & $\begin{array}{c}26 \\
(46.00)\end{array}$ & 148 & 1.85 & $\mathrm{X}$ \\
\hline 9 & $\begin{array}{l}\text { Better market } \\
\text { facilities are } \\
\text { available at } \\
\text { present }\end{array}$ & $\begin{array}{c}48 \\
(60.00)\end{array}$ & $\begin{array}{c}24 \\
(30.00)\end{array}$ & $\begin{array}{c}08 \\
(10.00)\end{array}$ & 200 & 2.50 & II \\
\hline 10 & $\begin{array}{l}\text { Better input } \\
\text { facilities are } \\
\text { available }\end{array}$ & $\begin{array}{c}14 \\
(17.50)\end{array}$ & $\begin{array}{c}52 \\
(65.00)\end{array}$ & $\begin{array}{c}14 \\
(17.50)\end{array}$ & 160 & 2.00 & VII \\
\hline 11 & $\begin{array}{l}\text { Better for those } \\
\text { residing near the } \\
\text { cities }\end{array}$ & $\begin{array}{c}69 \\
(86.25)\end{array}$ & $\begin{array}{c}11 \\
(13.75)\end{array}$ & $\begin{array}{c}00 \\
(0.00)\end{array}$ & 229 & 2.86 & I \\
\hline 12 & $\begin{array}{l}\text { Increases } \\
\text { diversification }\end{array}$ & $\begin{array}{c}24 \\
(30.00)\end{array}$ & $\begin{array}{c}49 \\
(61.25)\end{array}$ & $\begin{array}{c}07 \\
(08.75)\end{array}$ & 177 & 2.21 & V \\
\hline 13 & $\begin{array}{l}\text { Less dependency } \\
\text { upon cereal crops }\end{array}$ & $\begin{array}{c}00 \\
(0.00)\end{array}$ & $\begin{array}{c}59 \\
(73.75)\end{array}$ & $\begin{array}{c}21 \\
(26.25)\end{array}$ & 139 & 1.73 & XI \\
\hline
\end{tabular}

** Parenthesis indicate the respective percentages 
The results of the study pertaining to constraint found that among constraints related to inputs perceived the majority of the respondents 60.00 per cent were found under low category. Hence it can be concluded that farmers are not facing input problems as inputs are easily available for them. Among constraints related to market Study shows that 52.50 per cent of the respondents came under a low category of marketing constraints.

Therefore marketing of the flowers is also not a big issue. While among constraints related to production, the majority of the respondents 56.25 per cent were found facing more problems related to production and falling under the medium category. Hence it can be concluded that production is comparatively low. Among constraints related to technical guidance majority of the respondents 47.50 per cent were under medium category having lack of knowledge and required technical guidance and in case of psychological constraints Majority of the respondents 48.75 per cent were under low category regarding psychological constraint hence, it can be concluded this is not so serious among others.

The specific areas which the flower growers perceived more bright as prospects of commercial flower cultivation. The weighted mean about different items of prospects, rank order of different items revealed that the farmers perceived that marigold farming was found better only for those, residing near cities, was ranked 1st (weighted mean 2.86). This indicated that farmers perceived marigold cultivation much better in terms of price of sale of product. Whereas, increasing demand ranked 12th (weighted mean 1.72).

It can be concluded from the study that it is better for additional income to cultivate flowers, high prices of flowers, gives assured income, quick production, demand is increasing day by day, low production cost comparatively and easy to produce. Training is most important about marigold cultivation for the farmers so as to overcome the problems or constraints coming while cultivation. Training needs regarding plant protection, application of herbicides, use of water and storage of post-harvest flowers etc. department of horticulture and related KVK are present seminars and training courses to promote the flower cultivation.

The major problems faced by the respondents in effective functioning were: price problems, delay in getting loans, improper demand and supply chain commodities, marketing of products and transportation.

\section{References}

Anonymous, (2003). Indian Horticulture Database. National Horticulture Board, Ministry of Agriculture Govt. Of India, Gurgaon.

Anonymous, (2014-15). Ministry of Agriculture and Farmers Welfare Govt. of India. Retrieved data from Annual report of 2014-15.

Anonymous, (2015). Indian Horticulture Database. hotharyana.gov.in Annual report 2015-16.

Anonymous, (2016-17). Ministry of Agriculture and Farmers Welfare Govt. of India .Retrieved data from Annual report of 2016-17.

Balasubramaniam, A.S. (1996). "Techno Economic Aspects of Raising Carnation Cut-flowers," Fanner and Parliament, 32(1).

Chand, R. (1994). Study on media-mix for transfer of rice protection technology. M.Sc. thesis (unpublished), CCS Haryana Agricultural University, Hisar

Katyayan, B. (1989). Flower can turn gold mines. Indian Farmer Times, 6(10): 1314. 
Kamboj, M. (2011). Communication gap and constraints in kinnow production technology. M.Sc. Thesis (unpublished), CCS Haryana Agricultural University, Hisar.

Manju, Punia, D., Sapna and Hsija, R.C. (2010). Constraints in flower cultivation a sociological appraisal. MKK Publications, Kolkata, India. 28 (1B): 512-515.

Mukherjee, D. (1997). "Prospects and Problems of Commercial Floriculture in Himachal Pradesh," Floriculture Today, $1(2)$.

Nirmala, D. and Manmohan, S. (1998). "Marketing Efficiency of Cut-flower Market," Indian Journal of Economics, 76(4).
Ramamurthi, K.,Gupta, and Kumar, J. Vasantha (1997). Adoption level of farm women in turmeric production and processing. Journal of Extension Education, 7(4):1832-1835.

Shrivastava, R., Sarkar, K.K. and Shrivastava, P. (2010). Analysis of problems faced by the farmers in adoption of control measures of diseases of rice. Journal of International Academicia, 14(2): 260266.

Sanjeev, M.V. and Singha, A.K. (2010). Training needs analysis of farmers of Arunachal Pradesh. 10 (1): 83-93.

Singh, B. (1997). Floriculture An emerging industry in India. Journal of Indian Horticulture, 8(2): 47-50.

\section{How to cite this article:}

Pankaj Yadav and Dahiya. D. S. 2020. To Study the Pre and Post-Harvest Constraints and Prospects Level Confronted by the Marigold (Tagetes erecta L.) Growers in Gurugram and Jhajjar Districts of Haryana, India. Int.J.Curr.Microbiol.App.Sci. 9(06): 194-203. doi: https://doi.org/10.20546/ijcmas.2020.906.026 